\title{
Św. Paisjusz (Wieliczkowski) i duchowe skarby św. Góry Atos dla Rosji
}

\author{
Tomasz Kuprjanowicz \\ Chrześcijańska Akademia Teologiczna w Warszawie \\ Polska \\ t.kuprjanowicz@interia.pl
}

Tomasz Kuprjanowicz, Saint Paisius (Velichkovsky) and spiritual treasures of Holy Mouth Athos for Russia, Elpis, 19 2017: 133-137.

\begin{abstract}
Saint Ignatius (Bryanchaninov) believed that works Holy Fathers translated by saint Paisius (Velichkovsky) had so much "great ascetic honour" that they cannot be replaced by any other translation. Reading the Holy Fathers, as St. Ignatius emphasised, is particularly important for understading Holy Scripture. The biblical authors and Fathers were inspired by the same Spirit and for this reason Scripture and Tradition (in this case - the legacy of the Holy Fathers) compile one whole and cannot be divided. The Orthodox Church only accepts interpretation given by the Holy Spirit and the understanding of Scripture by the Fathers of the Church as inspired by the same Spirit. Having returned to Russia, St. Paisios's numerous disciples brought with them the renewed patristic tradition and manuscripts of the Holy Fathers' writings translated by St. Paisios. This contributed to the renewal of the Russian Orthodox Church and its monastic life.

Streszczenie: Święty biskup Ignacy (Branczaninow) uważał, że dzieła Świętych Ojców przetłumaczone przez świętego Paisjusza (Wieliczkowskiego) mają „taką godność ascetyczną”, że ich nie może zamienić żadne inne thumaczenie. Czytanie Świętych Ojców - podkreślał św. Ignacy - jest zwłaszcza ważne dla zrozumienia Pisma Świętego. Biblijni Autorzy i Ojcowie byli natchnieni jednym i tym samym Duchem i dlatego Pismo i Tradycja (w danym przypadku - spuścizna Świętych Ojców) zestawiają jedną całość i nie mogą być rozdzielane. Prawosławna Cerkiew akceptuje wyłącznie interpretację Duchem Świętym, a rozumienie Ojcami Cerkwi Pisma natchnione jest tym samym Duchem co i samo Pismo Święte. Liczni uczniowie św. Paisjusza powróciwszy do Rosji przynieśli ze sobą odrodzoną tradycję patrystyczną i rękopisy przetłumaczonych przez św. Paisjusza dzieł Świętych Ojców. To sprzyjało odrodzeniu mniszego życia i całej Rosyjskiej Cerkwi.
\end{abstract}

Keywords: works of the Holy Fathers, St. Paisius (Velichkovsky), Holy Mount Athos, Russia, Church, disciples

Slowa kluczowe: dzieła Świętych Ojców, św. Paisjusz (Wieliczkowski), św. Góra Atos, Rosja, Cerkiew, uczniowie

\section{Wstęp}

W Rosji począwszy od czasów panowania Piotra I stan mniszy podlegał bardziej lub mniej jawnym prześladowaniom. Jednym z wewnętrznych przyczyn było to, że do XVIII wieku dokonało się już w znacznym stopniu odstąpienie mnichów od patrystycznej tradycji, obniżył się jego duchowy poziom, a więc i autorytet monastycznego życia. Zwłaszcza silnym zewnętrznym ciosem dla mnichów było wprowadzenie monasterskich stanów (монастырских штатов) w 1764 roku. Na skutek tego liczba wychodźców z Rosji na Atosie i w Mołdawii, do liczby których należał i św. Paisjusz (Wieliczkowski) stała się „,сильно увеличиваться, так что в то время от Св. Синода были безчисленные публикации об отыскании скрывавшихся"'.

Właśnie w tym niekorzystnym czasie św. Paisjusz (Wieliczkowski) odrodził starożytną tradycję ojców monastycyzmu. Ks. Sergiusz Czetwierikow o św. Paisjuszu pisał: „Он дал ясные определения основной цели монашеской жизни, указал средства к достижению этой цели и подготовил лиц, способных осуществлять эту

Старијы отец Паисий Величковский и отеи Макарий Оптинский и их литературно- асксетическая деятельность. М.: 1909, s. 29. цель при помоши указанных им средств. Своим примером, деятельностью и переводами старец Паисий вызвал огромное духовное движение в православном монашестве, особенно заметное в России, где оно охватило не только иноков, но и светское общество всех классов"

Liczni uczniowie św. Paisjusza powrócili do Rosji. Przynieśli oni ze sobą odrodzoną tradycję patrystyczną i rękopisy przetłumaczonych przez św. Paisjusza dzieł Świętych Ojców33. Ks. S . Czetwierikow uważa, że wpływ starca Paisjusza rozpowszechnił się przy pomocy ponad 200 jego uczniów i ich następców w więcej niż 100 monasterach znajdujących się w 35 diecezjach ${ }^{4}$. To sprzyjało odrodzeniu mniszego życia i całej Rosyjskiej Cerkwi.

\footnotetext{
Четвериков С., прот. Молдавский стареи Паисий Величковский. Париж 1988, s. 5

3 Zachowała się tylko część rękopiśmiennej spuścizny św. Paisjusza. Święty biskup Ignacy informował: «Нямецкие старцы пишут, что у них прежде было много рукописей, но большая часть из них погорела при случавшихся в монастыре пожарах» (Письмо иеросхимонаху Макарию (Иванову) от 11.7.1846 // Игнатий (Брянчанинов), свят. Странствие ко вратам вечности. М.: 2001, s. 65).

4 Четвериков С., прот. Молдавский стареи Паисий Величковский. Париж 1988, s. 5-6.
} 


\section{1. Św. Paisjusz (Wieliczkowski) i skarby Św. Góry Atos}

Starzec Paisjusz (Wieliczkowski) wywodził się z pobożnej prawosławnej małorosyjskiej duchownej rodziny. Urodził się on 21 grudnia 1722 r. i był nazwany Piotrem ${ }^{5}$. Jeszcze w dzieciństwie Piotr przeczytał Pismo Święte Starego i Nowego Testamentu, żywoty świętych, pouczenia św. Jana Złotoustego i św. Efrema Syryjczyka, św. Doroteusza i innych ${ }^{6}$. W wieku 12 lat Piotr uczył się już w Kijowsko-Mohylańskiej Akademii. Później on o tym czasie pisał: „Взырая на честныхъ и святыхъ монаховъ мняшеся мне зрети Ангеловъ Божиих. И моляхся Господеви да и мене сподобитъ благодатию Своею святаго ихъ сего ангельскаго образа"7. W 1739 r. Piotr zostawił akademię i odszedł pielgrzymować. W 1741 r. został podstrzyżony w rasofor z imieniem Platon, a następnie w 1743 r. dostał się do Mołdawii, gdzie spotkał wielu nadzwyczajnych ascetów. Podczas pobytu na Wołoszczyźnie zgromadził on wielkie duchowe doświadczenie, oraz zdobył szacunek świętych ojców, którzy zaczęli go nazywać „юным старцем" ". W 1746 r. uzyskawszy ich błogosławieństwa Platon udał się na Świętą Górę. Pragnął on znaleźć duchowego ojca „седяща в безмолвии и внимающа себе емуже бы моглъ предати себе въ послушание", ale nie znalazł i zaczął żyć sam w skrajnej nędzy. W 1750 r. na Atos przybył starzec Bazyli Polanomierulskij. Dokonał on postrzyżyn Platona w mantję i nadał mu imię Paisjusz.

Stopniowo do Paisjusza zaczął napływać naród; sami budowali kielie i cierpieli nie do opisania nędzę. $\mathrm{Na}$ Atosie założyło się ich cenobityczne bractwo oparte na postanowieniach Świętych Ojców: pełnych bezinteresowności i posłuszeństwa. Paisjusz trudził się na równi z braćmi i był „образъ добродетелнаго жития всемъ во Святей Горе и новый обветшавшаго монашескаго жития обновитель" "10. Pо nocach przepisywał księgi. Badając dzieła Świętych Ojców, szukając w nich i pouczeń i wskazówek jak budować mnisze życie, Paisjusz zauważył w słowiańskich tłumaczeniach liczne uchybienia i niedokładności. Zajął się on przeglądem słowiańskiego tekstu patrystycznych ksiąg z celem ,По возможности исправить его, очистив от темных и неясных мест"11. Po długich poszukiwaniach, wędrówkach po monasterach, w pustelni Bazylego Wielkiego Paisjusz odnalazł księgi św. Piotra Damasceńskiego, św. Antoniego Wielkiego, św. Grzegorza

Паисий (Величковский), преп. Автобиография, жизнеописание и избраннье творения по рукописньлм источникам XVIII-XIX вв. / Сост. П.Б. Жгун, М.А. Жгун; общ. ред. Д.А. Поспелова, О.А. Родионова. М.: Русский на Афоне Свято-Пантелеимонов монастырь 2004, s. 31.

6 Tamże, s. 32.

Tamże, s. 36.

Tamże, s. 149.

9 Tamże, s. 152

10 Tamże, s. 156.

11 Четвериков С., прот. Молдавский стареи Паисий Величковский. Его жизнь, учение и влияние на православное монашество. Минск 2006, s. 119.
Synaity, św. Symeona Nowego Teologa i inne im podobne napisane „на самом чистом эллино-греческом языке”12. Greccy bracia przepisali dla niego część ksiąg.

W Mołdowłachii, dokąd starzec Paisjusz przesiedlił się po dwóch latach razem $\mathrm{z}$ całym swoim bractwem ${ }^{13}$, on po tych księgach sprawdzał i poprawiał słowiańskie tłumaczenia, a także zaczął urzeczywistniać nowe tłumaczenia ksiąg Świętych Ojców z starogreckiego języka. Razem ze starcem Paisjuszem tłumaczeniową działalnością i przepisywaniem ksiąg zajmowali się również najbardziej wykształceni z jego uczniów - literacka działalność u starca Paisjusza stała na bardzo wysokim poziomie ${ }^{14}$ łącząc się z duchowym i „умным деланием”. Niamieckij monaster był przy starcu Paisjuszu ,большим литературным центром, очагом богословски-аскетического просвещения"15. O znaczeniu działalności św. Paisjusza ks. Sergiusz Czetwierikow pisał, że on „дал ясные определения основной цели монашеской жизни, указал средства к достижению этой цели и подготовил лиц, способных осуществлять эту цель при помощи указанных им средств"16.

O konieczności podążenia za wolą Bożą ukazaną w Tradycji Prawosławnej Cerkwi i w szczególności w ascetycznych dziełach Świętych Ojców św. Paisjusz pisał do starca Teodozjusza: „Ведая известно от учений и заповедей Богоносных отец наших, яко имущему под своим окормлением братию неподобает по своему разуму и разсуждению наставляти и учити их, но по истинному и правому разуму Божественного писания, якоже Божественнии Отцы учителие Вселенстии, такожде учителие и наставницы монашескаго жития, просветившеся от благодати Пресвятаго Духа, учат... того ради, аки основание непоколебимое во истинное и непрелестное и незаблудное от истиннаго пути Божия наставление, и бедной моей души и святой братии, положих Божественное писание Ветхаго и Новаго Завета, и истинное его благодатию Пресвятаго Духа толкование, сиречь учение Богоносных Отец наших Вселенских учителей и наставников монашескаго жития, святые Соборы, и вся Апостольская и Соборная и Святых Отец правила, яже содержит Святая, Соборная и Апостольская Восточная Церковь"17.

O tym mówi się w „Послании старца Паисия иеросхимонаху Агафону, начальнику святыя Поляноворонския обители со всею о Христе братнею” z 1793 roku: „Ревность Божественную и веру несумненную имейте к Книгам Отеческим, и ко учению в них обретающему-

\footnotetext{
12 Tamże, s. 122-123.

13 Tamże, s. 123.

14 Паюл Иван. Славянские ученики преподобного Паисия XVII - начала XIX веков. Диссертация на соискание ученой степени кандидата богословия. Сергиев Посад 2001, s. 63.

15 Флоровский Г., прот. Пути русского богословия. Paris 1988, s. 127. 16 Четвериков Сергий, прот. Молдавский стареи Паисий Величковский. Его жизнь, учение и влияние на православное монамество. Минск 2006, s. 4.

17 От письма Стариа Паисия, еже писа к Стариу Феодосию // Житие и писаниа молдавскаго стариа Паисия Величковскаго. М.: 1847, s. 211.
} 
ся: еже есть Писанию Божественному, и всех Учителей Вселенских, и всея Церкве разуму... занеже един и тойжде Дух Святый действова, якоже во Учителех Вселенских, тако и во Святых Отцех учителех и наставницех монашескаго жития" 18 .

$\mathrm{W}$ „Послании братиям, оставшимся в Драгомирнском монастыре" św. Paisjusz pisze, że uważne czytanie dzieł Świętych Ojców oświeca rozum człowieka i daje zapał do wykonywania Bożych Przykazań ${ }^{19}$.

\section{Rezultaty ciężkiej pracy św. Paisjusza (Wieliczkowskiego)}

We wspomnianym liście do starca Teodozjusza św. Paisjusz wylicza Świętych Ojców-Ascetów, których dzieła on tłumaczył. To przede wszystkim święci autorzy Fiłokalii: Исихий Пресвитер Иерусалимский, Фнлофей Синаит, Феодор Едесский, Исаак Сирин, Петр Дамаскин, Диадох, Нил, Фалассий, Григорий Синаит, Симеон Новый Богослов, Иоанн Кассиан Римлянин, Антоний Великий, Исаия Отшельник, Феодор Студит, Макарий Великий, Марк Подвижник, Никита Стифат, Каллист Патриарх Цареградский і Игнатий Ксанфопулы, Каллист Катафигиот, Максим Исповедник, Симеон Солунский. Święty Paisjusz wspomina także Житие святого Григория Синаита. napisane uczniem jego Каллистом Патриархом, Патерик Великий Скита Египетского, a także pisma преподобного Нила Сорского ${ }^{20}$. Święty Paisjusz tłumaczył także pisma преподобного Иоанна Лествичника, блаженного Каллиста Тиликуди ${ }^{21}$, Илии Екдика ${ }^{22}$, Иоанна Златоустого, Григория Паламы, Марка исповедника Галатийского, Мелетия исповедника Галисийского, Аввы Аммона, Зосимы, Феогноста, Симеона митрополита Евхаитского $^{23}$. „Послание от всех Святогорцев царю Михаилу Палеологу" 24 i inne.

O tym, jakie znaczenie przywiązywał starzec Paisjusz do duchowej spuścizny świętych Warsonofiusza i Jana opisane jest w przedmowie książki odpowiedzi tych wielkich starców: „Блаженныя памяти Старец Паисий... великое возъиме желание, еже бы еще в жизни своей, обрести целую книгу святаго Варсануфия, и перевести на молдавский и славянороссийский языки... говоря: яко...

\footnotetext{
18 Переписка стариа Паисия относительно хульника молитвы Иисусовой иеромонаха Феопемпта. Рукоп. БАН, ш. 1.3.1.24 // Леонид (Поляков), иером. Схиархнмандрит Паисий Велнчковский и его литературная деятельность. Кн. 3. Л.: 1956, s. 279.

19 Леонид (Поляков), иером. Схиархимандрит Паисий Величковский... Кн. I, s. 137.

20 Житие и писания молдавскаго старияа Паисия Величковскаго. M.: 1847, s. 212-225.

21 Рук. БАН, 13.1.9, л. 129 // Леонид (Поляков), иером. Схиархимандрнт Паисий... Кн. 2, s. 411.

22 Рукоп. с6. БАН, 13.5.7 // Леонид (Поляков), иером. Схиархимандрит Паисий... Кн. 2, s. 412.

23 Переводы творений этих отцов помещены в сборнике „Востргнутыле класы в пищу души...»

24 Рукоп. сб. БАН, 13.5 .5 , л. 69.
}

великое духовнаго разума сокровище содержит целая святаго Варсануфия книга" 25 .

Badacz Jacimirski przytacza listę rękopiśmiennych ksiąg biblioteki Niamieckiego monasteru przepisanych św. Paisjuszem i jego najbliższymi uczniami składający się z 276 punktów ${ }^{26}$. Jest to ważne świadectwo o składzie pism Świętych Ojców leżących jako fundament nauczania i działalności starca Paisjusza. Ta lista pokazuje jakich Świętych Ojców pisma były najbardziej używane w bractwie św. Paisjusza. Wyliczamy tutaj tych Świętych Ojców, których dzieła są obecne na liście (w nawiasach ukazana ilość rękopisów):

Агапита диакона (I), Антония Великого (1), Варсануфия аввы (2), Василия Великого (7), Василия Поляномерульского (1), Выписки старца Паисия (4) (zawierają dzieła Афанасия Александрийского, Геннадия Схолария, Германа патриарха Константинопольского, Григория Паламы, Димитрия Ростовского, Досифея патриарха Иерусалимского, Евагрия, Евлогия патриарха Александрийского, Ефрема патриарха Антиохийского, Иоанна Дамаскина, Иоанна Златоустого, Исаии Отшельника, Каллиста патриарха Константинопольского, Максима Исповедника, Марка Ефесского, Софрония патриарха, Филофея, Юстиниана), Григория Синаита (5), Григория Паламы (7), Димитрия Ростовского (5), Диадоха епископа Фотикийского (6), Дионисия Ареопагита (2), Добротолюбие в переводе преподобного Паисия (4), Дорофея аввы (7), Ефрема Сирина (1), Григория Синаита (1), Изложение правилам апостольским и отеческим, имея Толкование Алексия диакона и законохранителя Аристина (I ), Илариона Великого (1), Иоанна Дамаскина (2), Иоанна Златоустого (2). Иоанна Кассиана Римлянина (4), Иоанна епископа Карпафийского (2), Иоанна Лествичника Синайского (8), Иосифа Вриения (1), Исаии Отшельника (1), Исаака Сирина (9), Исихия пресвитера Иерусалимского (9), Каллиста Катафигиота (3), Каллиста патриарха Константинопольского и сподвижника его Игнатия Ксанфопулов (8), Макария Египетского (3), Максима Исповедника (4). Максима иеромонаха Пелопоннесского (1), Марка Постника аввы (3), Марка Ефесского (4), Никиты Стифата (5), Нила Постника Синайского (4). Нила Сорского (6), Патерик азбучный (2), Петра Дамаскина (11), Сборники (32) (zawierają dzieła Антония Великого, Афанасия Александрийского, аввы Варсонофия, Василия Великого, Василия архиепископа Кесарийского, Германа архиепископа Константинопольского, Григория Паламы, Григория Синаита, Диадоха, Димитрия Ростовского, Дионисия Ареопагита, аввы Дорофея, Епифапия Кипрского, Ефрема Сирина, Зосимы преп., Илариона Великого, Илии Екдика, Иоанна Дамаскина, Иоанна Златоустого, Иоанна Карпафийского, Иоанна Кассиана, Иоанна Лсстничника, аввы Исаии, Иси-

\footnotetext{
25 Преподобных отиеев Варсануфия Великаго н Иоанна руководство к духовной жсини. в ответах на вопрошения учеников. М.: 1852, s. III-VI.

26 Яцимирский А.И. Славянские и русские рукописи румынских библиотек. СПб.: 1905, s. 555-583.
} 
хия пресвитера Иерусалимского, Каллиста патриарха Константинопольского, Макария Римлянина, Максима Исповедника, Матфея Властаря, Мефодия Патарского, Никона Черногорца, Нила Синайского Постника, Нила Сорского, Паисия Величковского, Палладия монаха, Симеона Метафраста, Симеона Нового Богослова, Симеона Солунского, аввы Фалассия, Феогноста, Феодора Студита, Феодора Эдесского, Феодорита Кирского, Феофилакта архиепископа Болгарского, Филимона Отшельника, Филиппа пустынника, Филофея Синайского, и жития Афанасия Затворника Киево-Печерского, Василия Нового, Евфимия, Каллиста патриарха Константинопольского, Макария Исповедника, Никиты Стифата, Нила Синайского, Пахомия Великого, Пимена Киево-Печерского, рассказ об авве Филимоне), Симеона Метафраста (2), Симеона Нового Богослова (15), Симеона Солунского (2), Никона Черногорца (2), Филарета патриарха Московского (1), Филофея Синайского (14), аввы Фалассия Ливийского (1), Феодорита Блаженного (1), Феодора Эдесского (5), Феодора Студита (3).

$\mathrm{Na}$ tej liście przedstawieni są praktycznie wszyscy znani nam starożytni autorzy ascetycznych dzieł Wschodniej Prawosławnej Cerkwi.

O stosunku św. Paisjusza do dzieł Świętych Ojców świadczy jego odpowiedź namiestnikowi Sofronjuszowej Pustyni archimandrycie Teodozjuszowi, który zwrócił się z prośbą o przysłanie tłumaczeń ascetycznych pism Świętych Ojców. W nim starzec Paisjusz rekomenduje mu pozyskać przygotowywane do wydania w Wenecji greckie wydanie Fiłokaliii ${ }^{27}$ i radzi nie żałować środków na nabycie dzieł Świętych Ojców: „Не подобает ли и толикое число денег всеусердне иждити на стяжание таковаго безценнаго духовнаго сокровища? Не точию же сие, но аще бы воэпоследовала нужда, то не подобает ли и душу свою за стяжание онех ближняго ради пользы, положити? Воистину подобает. И аще на созидание странноприимницы каменныя, с покровом железным, толико положили есте иждивение: то не подобает ли несравненно большее иждивение на стяжание предреченных книг, вечныя ради своея и ближняго пользы, положити?"28.

W utworze przeciwko urągającym modlitwie Jezusowej św. Paisjusz pisze, że przyczyną zbłądzenia jest ich nieuctwo, oraz niedokładne czytanie Dzieł Świętych Ojców -Ascetów: „Аще бы вы со страхом Божиим и крепким вниманием, и несумненною верою, с трудолюбным испытанием и смиренномудрием прочитали книги Отеческия... то никогда же бы вам Бог попустил в таковый ров элохуления пасти"29.

Z tłumaczeń Dzieł Świętych Ojców starcem Paisjuszem najbardziej cennym jest tłumaczenie autorów

\footnotetext{
27 Житие и писания молдавскаго старияа Паисия Величковскаго. M.: 1847 , s. 224-225.

28 Tamże, s. 229-230

29 Свиток сочинения Старияа Архимандрита Отияа нашего Паисия... о умной молитве // Житие н писания молдавскаго стариа Паисия Величковскаго. М.: 1847, s. 180.
}

greckiej Filokalii, którzy po raz pierwszy byli wydani w Wenecji w 1782 roku. Słowiańskie tłumaczenie greckiej Filokalii, dokonane św. Paisjuszem - Dobrotolubie było wydrukowane już w 1793 roku troską zwolennika mniszego życia metropolity Sankt-Petersburskiego i Nowgorodzkiego Gabriela (Pietrowa; + 1799). J. Florowski tak ocenia to wydarzenie: „Издание словено-русского Добротолюбия было событием не только в истории русского монашества, но и в истории русской культуры вообще... Интересно сравнить, Феофан Прокопович был весь в ожиданиях и в новизне, в будущем, в прогрессе. И старец Паисий, - он весь в прошлом... в предании. Но именно он был пророком и предтечей... Возврат к истокам был открытием новых путей, был обретением новых кругозоров"з

Charakterystyczną właściwością tłumaczeniowej działalności św. Paisjusza jest bogobojna dokładność tłumaczenia. W przedmowie do książki św. Izaaka Syryjczyka starzec Paisjusz napisał: „В преводе сея книги, и прочем подобном моем труде, всегда употребляю образа превода именуемаго до слова, имже Божественное Писание и вся церковныя и прочия книги на славенский язык с греческаго преложены суть"з1.

Znaczenie tłumaczeń Świętych Ojców św. Paisjuszem słusznie ocenił jego zwolennik św. Ignacy (Brianczaninow), biskup Kaukaski i Czarnomorski: „Для монашества, которое жительствует по книгам Святых Отцов, необходим точный перевод с подлинников посредством лица вполне знающего монашескую жизнь. Таковым лицом без сомнения был старец Паисий. Русские же переводы не имеют этого достоинства" 32 .

\section{Zakończenie}

W historii rosyjskiej myśli, pisze prot. Jerzy Florowski, starzec Paisjusz ma swoje widoczne miejsce. Porzucił on Kijowską Akademię nie pragnąc uczyć się łacińskiej mądrości i odszedł do greckiego monasteru. „Это не был отказ от знания. Это был возврат к живым источникам отеческого богословия и богомыслия" "33. Starzec Paisjusz był prawdziwym uczonym, który dokładnie studiował rękopisy; „эта ученая добросовестность старца Паисия - характерная черта его духовного строя, во всем очень трезвого, вдумчивого и в то же время глубокого" 34 . Paisjusz był rzadkiego talentu duchowym nauczycielem. W monasterach na Atosie i w Mołdawii «oH

\footnotetext{
30 Флоровский Г., прот. Пути русского богословия. Парнж 1988 , s. 127.

31 Исаак Сирин, прп. Слова духовно-подвижнмчсския, переведенныя с греческаго старцем Паисием Величковским. М.: 1854, s. XIV$-\mathrm{XV}$

32 Письмо к Оптинскому стариу Макарию (Иванову) от 30.4.1853 // Рук. сб. РГБ (Онтин. собр.), № 362, л. 124 об. // Игнатий (Брянчанинов), свт. Странствие ко вратам вечности: Переписка с оптинскими старияами... Москва 2001, s. 78.

33 Флоровский Г., прот. Пути русского богословия. Парнж 1988, 126. 34 Зеньковский В.В., прот. История русской философии. Париж 1948. Т.1, Ч.1, s. 63.
} 
восстанавливает лучшие заветы Византийского монашества... Это было возвратное движение русского духа к Византийским отцам» ${ }^{35}$. Jednym z najważniejszych rezultatów działalności starca Paisjusza było to, „что идеал духовной целостности и духовного устремления человека, воссозданный на основе святоотеческого наследия преп. Паисием для монашеского общежития, перешел в русскую церковную культуру, а некоторое время спустя стал влиять на религиозно-философскую мысль (славянофилы, Ф.М. Достоевский, К.Н. Леонтьев и др.)"36. О.T. Jermiszyn, żeby objaśnić pojęcie ideału starca Paisjusza przytacza wyciąg z jego dzieła „Об умной молитве”: „Из этих свидетельств [св. Отцов] явствует, что Бог, создав человека по образу Своему и подобию, ввел его в рай сладости, делать сады бессмертные, то

\footnotetext{
35 Флоровский Г., прот. Пути русского богословия. Парнж 1988, 126.

36 Ермишин О.Т. Философия религии: Концепциии религии в зарубежной и русской философии: учеб. пособие. 2-е изд., испр.
} M.: 2012, s. 131. есть мысли Божественные, чистейшие, высочайшие и совершенные, по святому Григорию Богослову. И это есть не что иное, как только то, чтобы он, как чистый душою и сердцем, пребывал в зрительной, одним умом священнодействуемой, благодатной молитве, то есть в сладчайшем видении Бога, и мужественно, как зеницу ока, хранил ее, как дело райское, чтобы она никогда в душе и сердце не умалялась" ${ }^{\prime 3}$.

Prot. Bazyli Zieńkowski podkreśla wyjątkowe znaczenie wpływu św. Paisjusza na odrodzenie w Rosji stanu mniszego. „C огромным педагогическим талантом Паисий соединял мудрость старца, светлый взгляд на человека и твердое сознание того, что первое дело для каждого человека есть правильное устроение его духовной жизни" 38 .

\footnotetext{
37 Cyt. za: Tamże, s. 131.

38 Зеньковский В.В., прот. История русской философии. Париж 1948. T.1, Ч.1, s. 63.
}

\section{Bibliografia}

Восторгнутые класы в пищу души, то есть несколько переводов из святых отиев Стариа Паисия Величковскаго. Москва 1849.

Ермишин О.Т. Философия религии: Конщепџии религии в зарубежной и русской философии: учеб. пособие. 2-е изд., испр. Москва 2012.

Житие и писания Молдавскаго Стариа Паисия Величковскаго. С присовокуплением предисловий на книги св. Григория Синаита, Филофея Синайскаго, Исихия Пресвитера и Нила Сорскаго, сочиненных другом его и спостником, Старием Василием Поляномерульским, о умном трезвении и молитве. Москва 1847.

Зеньковский В.В., прот. История русской философии. Париж 1948. Т.1, Ч.1.

Игнатий Брянчанинов, свт. Странствие ко вратам вечности: Переписка с оптинскими стариами и П. П. Яковлевым, делопроизводителем свт. Игнатия. Москва 2001.

Исаак Сирин, прп. Слова духовно-подвижнмчсския, переведенныя с греческаго старием Паисием Величковским. Москва 1854.

Леонид (Поляков), иером. Схнархимандрит Паисий Величковский и его литературная деятельность. Диссертация на соискание ученой степени магистра богословия. Кн. 1-3. Ленинград 1956. [Maszynopis].
Паисий (Величковский), преп. Автобиография, жизнеописание и избранные творения по рукописным источникам XVIII-XIX вв. / Сост. П.Б. Жгун, М.А. Жгун; общ. ред. Д.А. Поспелова, О.А. Родионова. М.: Русский на Афоне Свято-Пантелеимонов монастырь 2004.

Паюл Иван. Славянские ученики преподобного Паисия XVII - начала XIX веков. Диссертация на соискание ученой степени кандидата богословия. Сергиев Посад 2001.

Преподобных отиев Варсануфия Великаго н Иоанна руководство к духовной жизни. в ответах на вопрошения учеников. Москва 1852.

Стариы отеи Паисий Величковский и отеи Макарий Оптинский и их литературно- асксетическая деятельность. Москва 1909.

Флоровский Г., прот. Пути русского богословия. Парнж 1988.

Четвериков С., прот. Молдавский стареи Паисий Величковский. Париж 1988.

Четвериков С., прот. Молдавский стареи Паисий Величковский. Его жизнь, учение и влияние на православное монашество. Минск 2006.

Яцимирский А.И. Славянские и русские рукописи румынских библиотек. Санкт Петербург 1905. 
ISSN 1508-7719

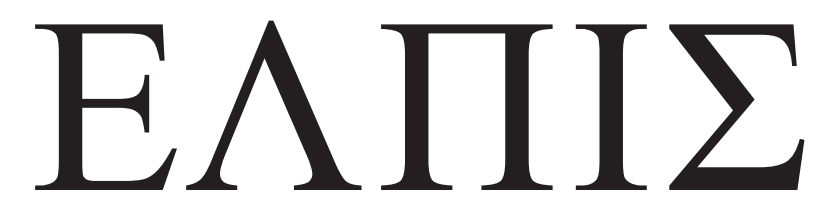

CZASOPISMO TEOLOGICZNE KATEDRY TEOLOGII PRAWOSŁAWNEJ UNIWERSYTETU W BIAŁYMSTOKU

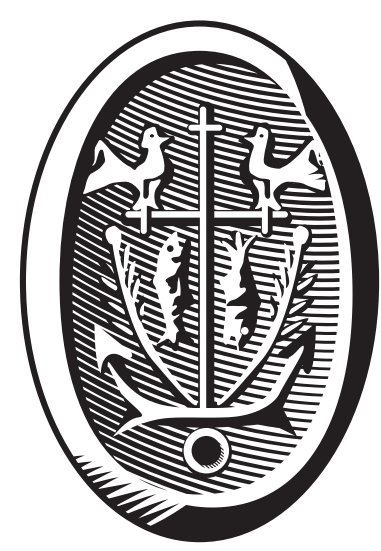

ADRES REDAKCJI

15-097 Białystok, ul. M. Skłodowskiej-Curie 14 tel. 85 745-77-80, e-mail: redakcja@elpis.edu.pl www.elpis.uwb.edu.pl 